\title{
ECONOMIC DUALISM AND FINANCE: THE LOWER MISSISSIPPI DELTA
}

\author{
William Weber and Michael Devaney*
}

\begin{abstract}
A multiple discriminant model is used to test the pervasive nature of economic dualism in the Lower Mississippi Delta Region (LMDR). Much of the policy discussion by The Delta Commission and the Congressional Delta Caucus has tended to focus on local financial constraints. While bank deposits and restrictive branching laws entered the discriminant function, our results suggest that the problems of the Delta are economically and socially pervasive. In addition to finance, public policy in the LMDR should also promote investment in human capital.
\end{abstract}

\section{INTRODUCTION}

The Lower Mississippi Delta Region (LMDR) has been certified by the U.S. Congress as the poorest region in the United States-poorer than Mr. Roosevelt's Tennessee Valley or Mr. Kennedy's Appalachia. The region is comprised of 219 counties in seven states (see Figure 1). In the most depressed counties, poverty rates approach 50 percent and infant mortality rates exceed those of Third World countries like Cuba and Chile (Lower Mississippi Delta Commission 1990).

In 1988, the 100th U.S. Congress passed the Lower Mississippi Delta Development Act and established a commission to study the region and make policy recommendations. Former state's chairman of the LMDR Commission was President Bill Clinton, and the previous co-chair of the Congressional LMDR Caucus was Secretary of Agriculture Mike Espy. Both have been strong advocates of alternative financing methods in the LMDR as well as other economically depressed regions. Suggested financial strategies include the creation of Community Development Corporations (CDC) and the creative use of securitized debt markets (Emerson and Espy 1992; "A Voter's Guide to the Issues" 1992). Consistent with the LMDR report, Congressmen Espy and Emerson cosponsored legislation to establish a LMDR Development Bank (Espy and Emerson 1992).

The role of financing in rural economic development has been the subject of some debate. The classic interpretation is that capital is mobile and will follow investment opportunities to the very ends of the earth if the return is sufficient to compensate for the risk. This view maintains that the slow growth of rural lending in the 1980s can be attributed to a shortage of entrepreneurship and investment

\footnotetext{
*Associate Professor, Department of Economics, Southeast Missouri State University, and .Associate Professor of Finance, Department of Accounting and Finance, Southeast Missouri State University, Cape Girardeau, Missouri, respectively.
} 


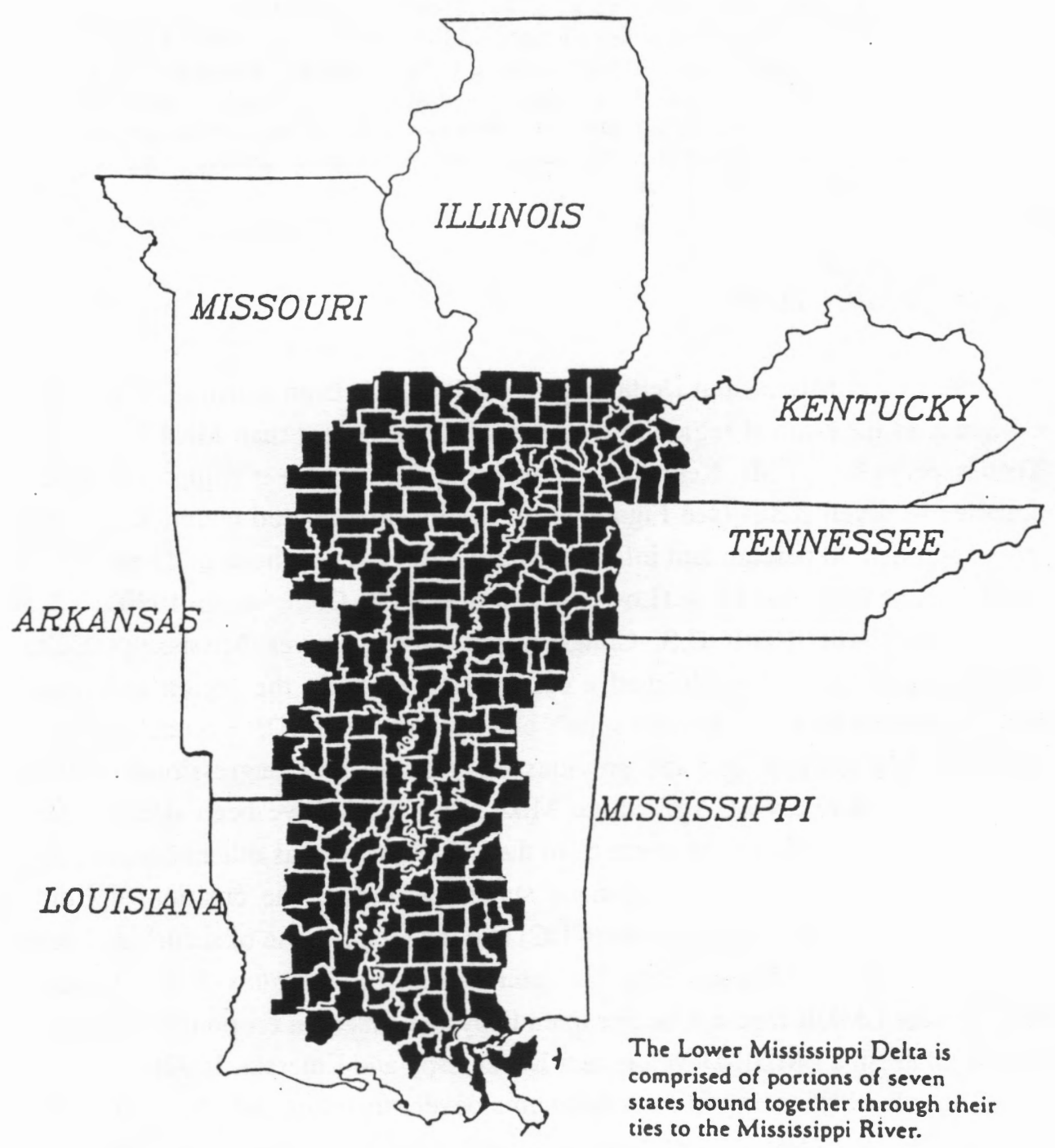


opportunities rather than rural credit rationing (Morris and Drabenstott 1989; 1991). According to this interpretation, business loans are demand driven, and programs to promote easy credit would be like "pushing on a string." An alternative view maintains that a shortage of finance is a binding constraint on rural development. This position asserts that banks play a pivotal role in rural credit markets and depository institution deregulation during the 1980s has had an adverse impact on rural banking markets and the communities they serve (Council of Northeast Economic Action, 1981; Horvitz and Petit, 1984; Lawrence and Wadkins, 1986; Lawrence and Klugman, 1992; Pulver and Hustedde, 1990).

In this paper, we argue that underdevelopment in the LMDR is economically and socially pervasive. Further, we assert that the LMDR exhibits many of the characteristics associated with dualistic societies and that finance may not be the binding constraint on economic development in the LMDR. We test the pervasive nature of economic dualism in the LMDR by examining a profile of economic and social indicators that discriminate most between the LMDR and the population of all non-Delta rural counties in the United States. The discriminant function generates a classification matrix that can be used to measure the power of the model in assigning Delta and non-Delta rural counties to the appropriate group.

The results have two important implications for public policy. One, if the LMDR is "dualistic," then it will exhibit a broad assortment of economic and social characteristics that render it structurally distinct from its non-dualistic counterparts. This result would support the assertion that in addition to the financial constraint, public policy should address additional dualistic variables in the discriminant function. Two, if the LMDR is truly an "economic region" and not simply defined by a political coalition, there should be a relatively small number of rural counties misclassified.

The next section provides a brief history of the lower Mississippi Delta. Section III discusses the "dualism" hypothesis in economic development. The fourth section discusses our results, and the final section presents our conclusions.

\section{BRIEF HISTORY OF THE LOWER MISSISSIPPI DELTA}

The economic and social problems of the Delta originated in its system of feudal agriculture. Compared to farming in other regions, Delta agriculture was labor intensive. Sharecropping provided a large pool of labor necessary to meet periodic needs. It also shifted risk from the landowners to the tenants, locking them into a system that precluded investment in human capital. Sharecroppers traded at a plantation-owned commissary using plantation scrip. Their economic 
domination was so complete that as late as 1965 Martin Luther King, Jr. visited with sharecroppers who had never seen United States currency (Oates 1982).

Unlike agriculture in other regions, mechanization and the widespread displacement of labor by capital did not occur in the Delta until after World War II. While the growth of manufacturing in northern cities "pulled" many rural residents, economists suggest that "push" factors play a much greater role in the decision to migrate, especially among low-skill workers (Greenwood 1975). The introduction of the mechanical cotton picker dramatically altered the technology of Delta agriculture (Lemann 1991) The first prototype cotton picker was tested by International Harvester in Clarksdale, Mississippi, on October 2, 1947. While several years passed before the cotton-picker was widely adopted, this event marked the end of the sharecropping system, perhaps the most overt remnant of slavery in America.

In 1947, Mississippi lawyer and writer David Cohn anticipated the epoch scale and consequences of the greatest internal migration in U.S. history when he wrote:

The coming problem of agricultural displacement in the Delta and the whole South is of huge proportions and must concern the entire nation. The time to prepare for it is now, but since we as a nation rarely act until catastrophe is upon us, it is likely we shall muddle along until it is too late. The country is upon the brink of a process of change as great as any that has occurred since the Industrial Revolution .... Five million people will be removed from the land in the next few years. They must go somewhere. But where? They must do something. But what? They must be housed. But where is the housing? (Cohn 1967).

What is most prescient in Cohn's remarks is the extent to which much of the current urban policy debate continues to be defined by this migration (Kozal 1991; Lemann 1991; Rainwater and Yancey 1967). Nicholas Lemann (1991) observes that noted black author Richard Wright surveyed the situation from another perspective and arrived at a conclusion strikingly similar to Cohn's:

Perhaps never in history has a more utterly unprepared folk wanted to go to the city; we were barely born as a folk when we headed for the tall and sprawling centers of steel and stone. We, who were landless upon the land; we, who had barely managed to live in family groups; we, who needed the ritual and guidance of institutions to hold our atomized lives together in lines of purpose; we, who had 
known only relationships to people and not relationships to things; we, who had our personalities blasted with two hundred years of slavery and had been turned loose to shift for ourselves (Wright 1941).

In addition to mechanization, import substitution and the advent of synthetic fiber hastened an out-migration that has continued to the present. Since 1970 , some rural Delta counties have lost as much as 20 percent of their population (Srinivasan 1988). Urban unemployment, crime, housing shortages, and strained social services argue against rural to urban migration as a solution to the problem of rural poverty. To many, it has become increasingly clear that the problem of poverty is best addressed at its source. While most of the research on the Delta migration has tended to concentrate on the socioeconomic-political impact on the urban destination, our focus is on those left behind.

\section{THE DUALISTIC MODEL}

The dualistic model of growth and development in less developed countries is most often associated with the works of Ranis and Fei (1961), Lewis (1954), and Jorgenson (1961). The analysis typically interprets the process of development as a gradual displacement of the informal traditional sector by a formal, modern, industrial sector. While "dualistic societies" are said to demonstrate a distinct cleavage characterized by widespread internal and external economic disparity, the phrase is too often invoked to describe any economic relationship between unequal parties. Hyperbole not only dilutes the intended meaning of economic dualism, it also trivializes the pervasive nature of the problem.

In dualistic systems, inequality is intractable. Trade models, such as Heckscher-Ohlin, which predict that factor movements across regions should result in an equalization of prices, fail to apply. Myrdal (1956) writes that in relationships between developed and underdeveloped regions, "market forces do not work towards equality in the renumeration to factors of production and, consequently, in incomes." He attributes the failure to a "process of circular and cumulative causation" inherent in dualistic relationships.

Much of the dualism debate involves the design of public policy to accelerate this process (Feldman 1989). Others refer to this interpretation as a dualistic model of "displacement." Bruton (1985) and Grabowski (1989) assert that high costs, especially enforcement costs, will likely overstate the net gains from these policies. Instead, they argue for an alternative development model directed specifically at the lagging, traditional sector. 
From the perspective of the lagging economy, the most compelling argument against the "displacement" model is the chronic failure of the dual sectors to converge (Boeke 1953; Myrdal, 1956; Schachter and Engelbourg 1988). What Cohn described as "muddling along" was essentially a passive policy of displacement. After a half century, the poverty, family structure, and tenant status of many black inner city households resembles a Delta sharecropper far more than the households in nearby suburbia. For many in the Delta and inner-cities, food stamps have replaced plantation scrip and public housing, the sharecroppers shack; but little of substance has changed.

Consistent with the dualistic model, the relative economic gap between the Delta and the rest of rural America has widened rather than narrowed (Smith 1992; Lower Mississippi Delta Commission 1990). Myrdal argues that dualism is self-perpetuating:

If left to take its own course, economic development is a process of circular and cumulative causation which tends to award its favours to those who are already well endowed and even to thwart the efforts of those living in regions that are lagging behind. The backsetting effects of economic expansion in other regions dominate the more powerfully, the poorer a country is (Myrdal 1956).

Dualism in the Delta has been characterized by the region's racial makeup, income inequality, infant mortality, low educational level, labor surplus, and inadequate infrastructure. External dualism manifests itself in the region's dependence on primary goods, capital upstreaming, brain drain, etc. Because of a high proportion of polluting industries per dollar of product, the Delta is a net exporter of clean air and water, a circumstance common to many Less Developed Countries (LDC). Dualism is also apparent in the region's inability to compete for federal resources. For example, in 1985 the 110 institutions of higher learning in the region captured only 59 percent of the research and development funds that went to Johns Hopkins University (Lower Mississippi Delta Commission, 1990). The theory of economic dualism and circular and cumulative causation would argue that these disparities are self-perpetuating and, left to the status quo, will tend to increase rather than diminish (Boeke 1953; Myrdal 1956).

In regard to private finance, The Delta Initiatives concluded that because the average loan/deposit ratio for the UnitedStates was 79.5 percent and only 73.6 percent in the Delta, Delta financial institutions were not adequately servicing their customers. The report maintains that if Delta loan/deposit ratios were equal to the national average, " 3.5 billion dollars in additional investment would take place on an annual basis" (Lower Mississippi Delta Commission 1990). The use 
of loan/deposit ratios as a measure of capital adequacy encounters several problems. Lawrence and Klugman (1992) suggest that rural affiliates of bank holding companies may be used to "warehouse" loans originated elsewhere. Banks in a local market may have a low loan/deposit ratio and still be providing credit to all creditable borrowers. The rural bank literature evaluates the adequacy of local markets in the context of "contestability theory" (Amel and Liang 1992; Whalen 1988, 1992). Rather than infer credit conditions from loan/deposit ratios, contestability theory suggests that market rivalry can be measured directly by change in market concentration, market entry, or profitability.

Kuznets (1971) maintained that the most distinctive feature of dualistic systems is that they developed relatively late compared to their non-dualistic counterparts. While different in degree from LDCs, we assert that the dualistic disparity in the LMDR is partially attributable to its late development vis-à-vis other rural regions. Because sharecropping labor was abundant, inexpensive, and shifted much of the operating risk from the landowner to the tenant, labor-intensive agriculture remained economically feasible in the Deep South longer than in other agricultural regions.

While it is not possible to quantify the unique history and cultural systems that define dualistic societies, we can identify manifestations of dualism. The following is a non-exhaustive list of six broad categories that frequently appear in the developmental literature as characteristic of dualistic societies (Boeke 1953; Jorgenson 1961; Kuznets 1971; Lewis 1954; Myrdal 1956; Schachter and Engelbourg 1988).

1. The Stock of Human Capital.

2. Income Inequality.

3. Constrained Private Investment.

4. Constrained Public Investment.

5. Labor Surplus.

6. Employment Composition and Export Base of the Economy.

Under each of the six categories, economic and demographic variables are selected as proxies to measure economic dualism. A detailed list of the variables in each category appears in Table 1 . All variables in Table 1 will be entered into the discriminant function and a step-wise procedure will be used to select the variables most significant in discriminating between LMDR and non-Delta rural counties. 


\section{TABLE 1}

Economic and Demographic Manifestations of Dualism

\section{Human Capital}

Percent of county population that is black (Race)

Median age of the county population (Med age)

Births per 1,000 to women under age 20 (Birth)

Female heads of household (Fem hh)

Proportion of population age 25-HS graduate (EdHs)

Proportion of population age 25 with college degree (EdCo)

Per capita spending on education (Educpop)

\section{Income Inequality}

Median income (Ybar81)

Theil entropy measure of income inequality (Theil)

Supplemental social security benefits (SSIPop)

\section{Constrained Private Investment}

Self-employed as \% civilian labor force (Self)

Growth in the housing stock 1970-1980 (HousGro)

Change in Herfindahl-Hirschman Index 1980-1988 (HHI)

Growth in county bank deposits 1980-1988 (DepGro)

State bank branching regulations UNIT-LIMITED-STATEWIDE

\section{Constrained Public Investment}

Physicians per 1,000 of the population (Physicians)

Hospital beds per 1,000 of the population (Hosp bed)

Per capita spending on highways (Highways)

Per capita taxes (Taxespop)

\section{Labor Surplus}

County unemployment (Unemploy)

Population growth rate 1970-1980 (Pop grow)

\section{Employment Composition and Export Base of Economy}

$\%$ of the labor force in Manufacturing (Manu)

$\%$ of the labor force in wholesale-retail trade (WR Trade)

$\%$ of the labor force in service industries (Serv)

$\%$ of the population living on farms (Farmpop)

Farm land as a \% of total land (Farmpct)

Dollar amount of capital per farm (Farm Cap) 


\section{MULTIPLE DISCRIMINANT ANALYSIS (MDA)}

Logit and probit analyses evolved from the regression model, while multiple discriminant analysis (MDA) is an extension of multivariate analysis of variance techniques (Altman et al. 1981). MDA is concerned with the comparisons of the distribution of one or more variables across mutually exclusive, known groups. ${ }^{1}$ Based on assumptions regarding the distribution of variables within the groups, the researcher can test for differences in mean variable vectors and/or covariance structures across the groups.

A stepwise procedure is used to define the discriminant function based on a Bayesian adjustment for $a$ priori estimates of group membership. MDA assumes multivariate normality and equality of covariance matrices. While research suggests the method is robust for deviations from the assumptions, diagnostics are used to test for violation of MDA assumptions. Specifically, we tested for homogeneity of the within group covariance matrices for the two groups. ${ }^{2}$ Each observation is classified based on its "score," and a significance test is applied to the classification matrix to determine the power of selected variables to discriminate between the two groups.

\section{Data}

The data for the study comes from two sources. Demographic data used in estimating the discriminant function is taken from the 1983 County Data Book published by the Census Bureau. The study includes the population of all rural counties appearing in the 1983 County Data Book. The financial data was taken from the 1980 and 1988 Summary of Deposits tape compiled by the Federal Reserve. The data tape lists county numbers and deposits for all federally insured banks and branches in the United States.

\section{Dualistic Variables}

Table 2 provides descriptive statistics for the variables included under each category of the Delta and non-Delta counties. Based on the County Data Book for the United States, there were 175 rural counties located in the LMDR and 2,154 non-Delta rural counties.

The first set of variables in Table 2 lists demographic groups that are associated with lower levels of human capital investment as well as direct investment in human capital. The first four variables in category one, percent of the population that is black (Race), median age of the population (Med age), the number of births to women under the age of 20 per 1,000 population (Birth), and the 
TABLE 2

Descriptive Statistics for LMDR and non-Delta Counties

\begin{tabular}{|c|c|c|c|c|}
\hline \multirow[b]{2}{*}{ Variable } & \multicolumn{2}{|c|}{ Non-Delta Counties } & \multicolumn{2}{|c|}{ LMDR Counties } \\
\hline & Mean & $\begin{array}{l}\text { Standard } \\
\text { Deviation }\end{array}$ & Mean & $\begin{array}{l}\text { Standard } \\
\text { Deviation }\end{array}$ \\
\hline \multicolumn{5}{|l|}{ Human Capital } \\
\hline Race* & 0.071 & 0.128 & 0.240 & 0.216 \\
\hline Med age & 31.544 & 4.002 & 30.800 & 3.947 \\
\hline Birth* & 4.082 & 3.861 & 5.357 & 3.553 \\
\hline Fem hh* & 0.075 & 0.030 & 0.104 & 0.037 \\
\hline EdHs* & 0.581 & 0.121 & 0.465 & 0.064 \\
\hline EdCo & 0.104 & 0.043 & 0.082 & 0.122 \\
\hline Educpop* & 332.025 & 116.669 & 257.654 & 69.281 \\
\hline \multicolumn{5}{|l|}{ Income Inequality } \\
\hline Ybar81* & 8330.10 & 1776.05 & 6726.21 & 1144.83 \\
\hline Theil* & 1.57 & 0.006 & 1.59 & 0.004 \\
\hline SSIPop* & 0.022 & 0.017 & 0.047 & 0.018 \\
\hline \multicolumn{5}{|c|}{ Constrained Private Investment } \\
\hline Self & 0.139 & 0.078 & 0.103 & 0.039 \\
\hline HousGro* & 0.252 & 0.169 & 0.207 & 0.122 \\
\hline HHI & -0.010 & 0.096 & -0.003 & 0.100 \\
\hline DepGro* & 0.614 & 0.456 & 0.538 & 0.253 \\
\hline UNIT* & .278 & .448 & .16 & .367 \\
\hline LIMITED & .479 & .449 & .84 & .367 \\
\hline STATEWIDE & .243 & .430 & .00 & .00 \\
\hline \multicolumn{5}{|c|}{ Constrained Public Investment } \\
\hline Physicians & 63.242 & 56.132 & 53.027 & 33.996 \\
\hline Hosp bed & 534.979 & 712.701 & 463.488 & 698.677 \\
\hline Highways & 67.374 & 50.412 & 52.736 & 32.111 \\
\hline Taxespop & 240.499 & 159.161 & 114.604 & 39.973 \\
\hline \multicolumn{5}{|l|}{ Labor Surplus } \\
\hline Unemploy* & 0.067 & 0.035 & 0.090 & 0.026 \\
\hline Pop grow* & 0.121 & 0.158 & 0.097 & 0.126 \\
\hline \multicolumn{5}{|c|}{ Employment Composition and Export Base of Economy } \\
\hline Manu* & 0.184 & 0.118 & 0.225 & 0.085 \\
\hline WR Trade & 0.170 & 0.035 & 0.160 & 0.028 \\
\hline Serv & 0.169 & 0.044 & 0.168 & 0.043 \\
\hline Farmpop & 0.119 & 0.103 & 0.075 & 0.050 \\
\hline Farmpct* & 59.663 & 31.275 & 53.618 & 23.364 \\
\hline FarmCap* & 312335.0 & 284061.0 & 273981.9 & 208827.4 \\
\hline
\end{tabular}

*Variables entering the discriminant function by the stepwise procedure. 
number of female heads of households (Fem hh), are all associated with low incidence of human capital investment.

The variable percent black was used instead of percent white or percent minority because a unique feature of the rural Delta is the relatively large percentage of Afro-Americans. While discrimination against other minorities in other areas such as the Southwest may be a contributing factor in underdevelopment, the historical and cultural origins of racism in the Delta and the South are unique. The large Hispanic population in the Southwest is a result of in-migration due to economic "pull factors," while the black population in the LMDR arose because of slavery; the region is currently experiencing net out-migration. ${ }^{3}$ On average, the Delta counties had a larger percentage of residents who were black and younger and had a larger rate of births to women under age 20 and more female heads of households than the non-Delta counties. While not prima facie evidence of under investment in human capital, a disproportionate number of Delta residents in each of these three categories suggests that on a per capita basis, the stock of human capital in the Delta is lower relative to non-Delta counties (Hanushek 1986).

Direct human capital investment is measured by the proportion of the county population that is over 25 years of age and a high-school graduate and is described by the variable EdHs, while EdCo measures the percentage of college graduates over 25 years of age. An additional variable measuring direct investment in human capital is per capita expenditures on education (Educpop). The LMDR counties have both a smaller proportion of high school (EdHs) and college graduates (EdCo). Delta counties also exhibited lower per capita expenditures on education (Educpop).

The second category of variables includes the level and distribution of income in each rural county. Per capita income in 1981 (Ybar81) was lower in the Delta counties than in the non-Delta counties. To account for the level of income inequality in each county, we constructed Theil's entropy measure. Let $\mathrm{s}_{\mathrm{i}}$ represent the share of total household income earned by the ith household. Theil's entropy measure is then $\mathrm{E}=-\Sigma_{\mathrm{i}} \mathrm{S}_{\mathrm{i}} \log \mathrm{si}$. When income is concentrated entirely in one household, entropy is at a minimum and the value of the index is $\mathbf{0}$. Therefore, a lower value for $\mathrm{E}$ indicates greater concentration of household income in the county. Since income data is not available by household, we calculate Theil's entropy measure using grouped income data. We consider six income groups: \$0$\$ 10,000 ; \$ 10,001-\$ 19,999 ; \$ 20,000-\$ 29,999 ; \$ 30,000-\$ 39,999 ; \$ 40,000-\$ 49,999$; and over $\$ 50,000$. On average, the LMDR counties had a higher Theil's entropy index, which indicates less inequality in the distribution of income in Delta relative to non-Delta counties, suggesting that residents are "equally poor." This is somewhat surprising since income inequality is frequently regarded as an obvious 
feature of the Delta. However, many of the largest landowners in the Delta reside elsewhere, and some evidence suggests an increased trend toward absentee land ownership.

The variable SSIPop is the proportion of residents receiving supplemental security income. Supplemental security income is provided primarily to individuals over age 65 whose income falls below a defined level, with the payment equal to the amount of the shortfall. For the LMDR and non-Delta counties, the average payment was $\$ 143$ and $\$ 142$ respectively; but the Delta counties had more than twice as many recipients -4.7 percent of the population-as compared to the non-Delta counties with only 2.2 percent of the population receiving aid.

Constrained private investment is measured by direct investment variables Self and HousGro and financial variables $\mathrm{HHI}$ and DepGro. The variable Self is the percent of the civilian labor force that is self-employed. The self-employed serve as a proxy for entrepreneurship, risk taking, and the number of small businesses in an area. With small businesses being the main engine of job growth in the last two decades, this variable also helps to describe the ability of a county to generate jobs and absorb surplus labor. Table 1 reveals that the LMDR counties had a smaller proportion of the civilian labor force self-employed. LMDR counties experienced less growth in the housing stock, (HousGro) than the non-Delta counties.

The private financial constraint is measured by growth in deposits (DepGro), change in county bank deposit concentration 1980-1988 (HHI), and the state banking regulatory environment (UNIT). Growth in deposits is the percentage change in county deposits for the period 1980-1988. As mentioned previously, the rural banking literature tends to emphasize local banking market rivalry in the context of contestability theory rather than loan/deposit ratios. Whalen (1992) used a four-bank concentration ratio as his measure of market rivalry, while Amel and Liang (1992) defined rivalry as the probability of market entry. While market concentration is subject to some limitations, it is a better measure of market rivalry in rural markets since potential competition from non-bank competitors is much more limited.

Most rural banks are small (40 percent have assets of less than $\$ 25$ million); consequently, they do not participate in the brokered deposit market) and most deposits originate locally. Therefore, growth in deposits and change in concentration should be reliable measures of the private financial constraint in rural counties. The Herfindahl-Hirschman Index (HHI) is calculated by squaring and summing the deposit share of the market accounted for by every bank in the county. Multiple branches of the same bank were treated as a single institution. Concentration for both the Delta and non-Delta counties decreased during the 1980s, but the average decrease was larger in the non-Delta. Bank deposits (DepGro) 
from 1980 to 1988 grew at a slower rate in the LMDR, and bank concentration declined for both Delta and non-Delta counties.

Another measure of potential competition is the state regulatory evironment for commercial banks. The variables UNIT, LIMITED, and STATEWIDE describe state branching regulations. Everything else being equal, potential competition is expected to be greatest in markets that allow STATEWIDE branching followed by LIMITED and UNIT. As of 1980, none of the counties in the LMDR allowed statewide branching. Eighty-four percent of Delta counties allowed limited branching and 16 percent allowed only unit banking. In order to avoid the problem of linear dependence, only the variable UNIT is included in the discriminant model.

An economy's ability to grow depends not only on private investment opportunities, but also on public investment in infrastructure and human capital. Firms considering expanding production in a region consider the quality of highways, schools, health care, and the level of taxes used to finance those activities. Ceteris paribus, the higher the taxes, the less attractive the region is to potential business entrants. However, firms will find it attractive to invest in regions where taxes are higher if the higher taxes are used to finance public expenditures that yield positive marginal benefits in excess of the higher taxes. The LMDR counties had less per capita spending on highways than the non-Delta counties. Other kinds of public expenditures, such as health care, can make it easier to attract industry and enhance the productivity of human capital. We proxy access to health care by the number of physicians in the county per 1,000 population (Physicians) and the number of hospital beds (Hosp bed) in the county. The LMDR counties again supply less in both of these areas than the non-Delta counties. The final variable under public investment is per capita taxes (Taxespop). Per capita taxes measure the local counties' willingness as well as ability to pay for more public services. Non-Delta counties have higher per capita tax revenues than Delta counties.

One of the distinguishing characteristics of dual economies is the existence of surplus labor in the less developed sector. To proxy surplus labor, we compared the unemployment rate (Unemploy) between the LMDR and non-Delta counties and found that the LMDR counties had a higher unemployment rate than the non-Delta counties. However, population growth (Pop grow) in the Delta was lower than the non-Delta.

The final category of variables is the employment composition and export base of the region. In dual economies, the less developed sector tends to export primary goods (especially agricultural products) into a competitive market. In the developed sector, however, firms tend to use greater amounts of capital and specialize in the production of products that use increasing returns to scale technologies. The technology of production tends to give the developed sector greater 
monopoly power that can be exploited when exporting goods to the primary sector. While detailed disaggregated data on the export base of the various non-farm sectors is unavailable, information on the percent of the civilian labor force employed in manufacturing (Manu), wholesale and retail trade (WR Trade), and services (Serv) may give some insight into the composition of the Delta economy relative to the non-Delta. We also examine the agricultural base of the rural economy by looking at the percent of the population residing on a farm (Farmpop), the percent of farm land relative to total land in the rural county (Farmpct), and the dollar amount of capital invested in each farm (Farm Cap).

Relative to the non-Delta counties, the LMDR counties had a higher proportion of the labor force employed in manufacturing, a smaller proportion in wholesale and retail trade, and the same proportion of the labor force employed in service industries. In addition, the LMDR had both a smaller percentage of the population living on farms and a smaller percent of land employed in farming. The LMDR also utilized a smaller amount of capital per farm than the non-Delta counties.

The test statistic for variables to enter the discriminant function is Wilk's statistic with a 15 percent significant level. ${ }^{4}$ Of the 27 variables described in Table 1, 16 were found to be significant discriminators between the LMDR and the non-Delta counties.

The human capital variables included in the stepwise function were Race, Fem hh, Birth, EdHs, and Educpop. The so-called "cycle of poverty" and the linkages to teenage pregnancy, female heads of household, and high school dropout rates have been well documented in studies of urban poverty. Our results suggest the "cycle" also applies to the Delta poor.

In the second category, all three variables were included in the stepwise. These include per capita income (Ybar81), the percentage of the elderly receiving supplemental social security benefits (SSIPop), and Theil's entropy coefficient. Based on the Theil statistic, the distribution of income or entropy measure indicated less inequality in the Delta than in non-Delta counties. This is somewhat surprising given frequent references to income inequality; however, this result may derive from the range of incomes used in constructing the index. It may also be a consequence of absentee ownership, especially landowners who reside elsewhere.

In the category measuring constrained private investment, the growth rate in the housing stock and the growth rate in county bank deposits both entered the discriminant function. While change in concentration did not enter, the regulatory variable UNIT was included. This suggests that restrictive banking laws may be a more important factor in Delta credit markets than collussion among incumbent banks. 
Of the four variables measuring constrained public investment, none were included in the discriminant function. This is somewhat surprising given the frequent references to underinvestment in "public infrastructure" in the region (Lower Mississippi Delta Commission 1990). Although the issue is still unsettled, Holtz-Eakin (1993) found that public capital has no effect on state or regional output. In the category Labor Surplus, both unemployment (Unemploy) and the growth in county population (Pop grow) entered the stepwise discriminant function. In the final category measuring the composition of the work force employed in the three sectors, only percentage of the population employed in manufacturing (Manu) was included in the discriminant function. Manufacturing is frequently associated with economic development and prosperity. However, this result suggests that a rural county may have a relatively large proportion of its work force employed in manufacturing and still be underdeveloped. Finally, farm land as a percent of total land (Farmpct) and the dollar amount of capital invested in each farm (Farm Cap) entered the discriminant function.

With the exception of constrained public investment, variables from the remaining five categories entered the discriminant function suggesting that the differences between the LMDR and non-Delta counties are socially and economically pervasive and not simply a matter of constrained financing (change in banking market concentration was not included). While the relative importance of the variables in the discriminant function cannot be determined, the large number of variables included from the "human capital" category suggests it is a major contributing factor to underdevelopment in the Delta. It also lends support to the assertion that a shortage of entrepreneurship, rather than finance, is one of several binding constraints on rural economic development in the 1980s.

Whether or not the LMDR can be defined as an "economic region" rather than a political coalition can be determined by an examination of the classification matrix. The number of observations classified as non-Delta and Delta counties from the discriminant function and the prior proportions are presented in Table 3. The proportional reduction in error statistic, tau, is calculated and indicates that the discriminant function made 34.18 percent fewer errors in classification than would be expected by chance. ${ }^{5}$ According to the classification matrix presented in Table 3, 33 Delta counties were misclassified as non-Delta and 180 of the nonDelta counties were misclassified as Delta counties.

An examination of the misclassified counties indicates that they included a total of 19 states that appear in Table 4. Eighty-nine, or 49 percent, of the counties misclassified as Delta are located in the seven states comprising the LMDR. The state with the largest number of counties misclassified as Delta was Alabama, which is not officially part of the LMDR. Alabama, along with the other seven states comprising the LMDR, accounted for 69 percent of the counties misclas- 
TABLE 3

Number of Observations and Percents Classified into Groups

From

Group

Non-delta

LMDR

Total

Non-delta

1974

180

2154

$\%$

91.64

8.36

100.00

LMDR

33

142

175

$\%$

18.85

81.15

100.00

Total

2007

322

2329

$\%$

86.17

13.82

100.00

Priors

0.9249

0.0751

TABLE 4

Misclassified Counties by State

Counties

Counties

State

Alabama

Misclassified as LMDR Misclassified as non-Delta

Arkansas

36

Florida

19

0

Georgia

Illinois

3

6

Indiana

23

4

1

Kentucky

Louisiana

13

Mississippi

Missouri

North Carolina

Ohio

Oklahoma

Pennsylvania

South Carolina

8

25

7

3

3

6

1

8

Tennessee

13

Texas

2

Virginia

West Virginia

2

$\underline{3}$

0

0

6

0

8

5

1

4

0

0

0

0

0

3

0

0

$\underline{0}$

Totals

180

33 
sified as LMDR counties. Twenty-five counties in Mississippi were misclassified as part of the LMDR even though not officially included in the region.

The largest number of LMDR counties misclassified as non-Delta occurred in Kentucky, which had eight misclassifications. Illinois and Arkansas each had six LMDR counties misclassified as non-Delta. These three states accounted for 61 percent of the LMDR counties misclassified as non-Delta. Our results support the contention that the structural economic problems confronting the LMDR also apply to rural regions in Alabama (36 counties) and Georgia ( 23 counties) as well as an additional 25 counties in Mississippi and 19 rural counties in Arkansas not officially included in the LMDR.

\section{v. CONCLUSIONS}

A multiple discriminant model and stepwise routine were used to identify a profile of variables selected from six categories that are characterized as manifestations of dualistic economies. Our results lead to the conclusion that the Lower Mississippi Delta Region exhibits many of the traits associated with economic dualism. In part, this may be attributed to the regions' late development vis-à-vis other agricultural regions. The operational interpretation typically applied to the resulting discriminant function is that decision makers who wish to bring about convergence should focus on those factors that discriminate most between mutually exclusive groups.

Two important public policy implications derive from our results. One, the socioeconomic problems of the Delta are pervasive in nature. Like many innercity residents, the Delta poor are characterized by high teenage pregnancy rates, high percentage of female head of households, low high-school graduation rates, and underinvestment in primary and secondary education. The cultural linkage between poverty in the LMDR and destination cities has been well documented (Kozal 1991; Lemann 1991). This literature suggests that policy regarding the Delta migration was essentially passive and could be characterized as a policy of "displacement." Rural to urban migration by the Delta poor relocated poverty without addressing the root cause. Our results suggest that in addition to financial programs, LMDR public policy should also promote investment in human capital.

The second policy implication of our results is that the problems afflicting the LMDR are shared by many more counties in the Deep South. Indeed, the MDA classification can be interpreted as a definition of an "economic region." However, misclassification of the 180 non-LMDR counties may be less severe than it initially appears. Of the 180 misclassified counties, 89 , or 49 percent, are in the seven states that comprise the LMDR. If Alabama, which has 36 counties 
misclassified as LMDR, is removed, then 62 percent of misclassified counties are in the seven states that comprise the political LMDR region. Excluding Alabama (36 counties) and the seven states comprising the LMDR (88 counties) leaves only 55 rural counties out of 2,154 that were misclassified by the model. While one may argue that the "economic definition" of the LMDR is too narrow, defining a region by geographically contiguous areas that share an important navigable waterway may have political and practical advantages over a fragmented economic definition.

Rather than compete with local banks, a LMDR Development Bank should fill "gaps" in the financial system. These gaps might include a micro loan program for small businesses neglected by the local banking system. Working in partnership with regional banks, a development bank could also participate in higher risk development projects with large potential benefit to the local community. By pooling loans, a development bank could also assist local banks in risk management.

The rural banking system in the United States is undergoing dramatic structural change. The Comptroller of Currency forecasts a 20 percent reduction in the number of rural banks over the next five years (Economic Research Service 1991). Many of these banks will be small since more than 40 percent of all rural banks have assets of less than $\$ 25$ million. A development bank could provide technical assistance to help small banks adapt to the changing environment and to identify new profit opportunities such as participation in the fledgling Farmer Mac program that provides a secondary market for agricultural and rural home loans.

The financial system works with, but not against, other economic and cultural forces. A development bank may fill gaps in the financial system, but it cannot reverse the entrenched poverty or the racial heritage described by Myrdal (1944) nearly 50 years ago as the "American Dilemma." The average black population in the LMDR is more than three times that in non-Delta rural regions. While racism may be a contributing factor to underdevelopment in other regions of the United States, it has not been institutionally ingrained to the same extent as the rural South. Afro-American popular culture, as well as its political orientation, is decidedly urban so that rural Afro-Americans may be the most underrepresented racial grouping in America. This observation, along with the fact that the rural poor are more likely to number among the "working poor," suggests that programs to address rural poverty, especially in the LMDR, deserve the attention of policymakers. 


\section{ENDNOTES}

1. An analysis of the distribution of independent variables caninfer which group generated observations on the independent variables. This concept has been referred to as a "resemblance" rather than probability. Resemblance has a traditional interpretation as a Bayesian posterior on group membership given values of the $m$ variables for an observation with unknown group membership. Suppose that there are two groups with $\mathrm{N}_{1}$ observations for which $\mathrm{y}=1$ and $\mathrm{N}_{2}$ observations for which $\mathrm{y}=0$ defining the groups. Let $\mathrm{x}_{1}$ and $\mathrm{x}_{2}$ denote the vector of explanatory variables for the two groups, with $m_{1}$ and $m_{2}$ denoting the means for the explanatory variables. Linear discriminant analysis tries to find a linear function, $\lambda x$ that provides the best discrimination between the two groups. The coefficient vector $\lambda$ is chosen so that the variance of between groups is maximum relative to its variance within groups. The variance between groups is $\lambda\left(\mathrm{m}_{1}-\mathrm{m}_{2}\right)^{2}$ and the variance within groups is $\lambda S \lambda$, where $S=\left\{1 /\left(N_{1}+N_{2}-2\right)\right\}\left\{\left(x_{1}-m_{1}\right)\left(x_{1}-m_{1}\right)^{\prime}-\left(x_{2}-\right.\right.$ $\left.\left.\mathrm{m}_{2}\right)\left(\mathrm{x}_{2}-\mathrm{m}_{2}\right)^{\prime}\right\}$. The coefficient vector $\lambda$ is chosen to maximize $\lambda\left(\mathrm{m}_{1}-\mathrm{m}_{2}\right) \lambda \lambda \lambda \mathrm{S} \lambda$.

2 . In the case of equal covariance matrices between the groups, the generalized squared distance from $x$ to group $t$ is

$D_{t}^{2}(x)=\left(x-m_{t}\right)^{\prime} S^{-1}\left(x-m_{t}\right)-2 \log ($ prior $)$, where prior $t_{t}$ is the prior probability that the observation belongs to group $t$. If the covariance matrices are unequal, the generalized squared distance from $x$ to group $t$ is

$D_{t}^{2}(x)=\left(x-m_{t}\right)^{\prime} S_{t}^{-1}\left(x-m_{t}\right)+\log \left(\mid S_{t} t\right)-2 \log ($ prior $t)$.

3. When "percent minority" rather than "percent black" was included as the racial variable in the discriminant function, there were 23 more non-Delta counties misclassified as Delta. These results are not reproduced here, but are available from the authors.

4. Define $\mathrm{k}=$ number of groups, $\mathrm{p}=$ number of variables, $\mathrm{N}=$ total number of observations, $N(I)=$ number of observations in the Ith group, $V=$ [Product of

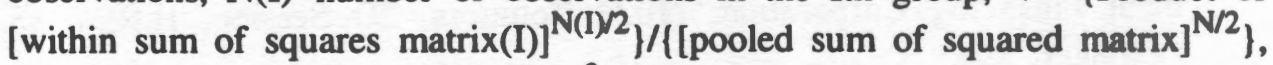
rho $=1-\left[\operatorname{sum}(1 /(\mathrm{N}(\mathrm{I})-1)-(1 /(\mathrm{N}-\mathrm{k}))]\left[\left(2 \mathrm{p}^{2}+3 \mathrm{p}-1\right) /(6(\mathrm{p}+1)(\mathrm{k}-1))\right]\right.$, and the degrees of freedom $=.5(\mathrm{k}-1) \mathrm{p}(\mathrm{p}+1)$. The test statistic is $-2 * \mathrm{rho} \mathrm{o}^{*} \log \left\{\left[\mathrm{N}^{\mathrm{pN} / 2} \mathrm{~V}\right] /\right.$ (product $\left.\mathrm{N}(\mathrm{I})^{\mathrm{pN}(\mathrm{I}) / 2}\right]$ \}. Tests for violations of MDA assumptions determined that, within group covariance, matrices were not equal. The chi-square statistic takes a value of 1316.5 with 120 degrees of freedom. The critical chi-square with 1 percent significance level is 135.8 . As a result, the two within group covariance matrices and the quadratic form for the discriminant function are employed to classify observations.

5. The proportional reduction in error statistic, tau, is calculated to give a standardized measure of improvement. Defining $\mathrm{N}_{\mathrm{c}}$ as the number of correct classifications, $\mathrm{p}_{\mathrm{i}}$ as the prior proportion for group $\mathrm{i}, \mathrm{N}_{\mathrm{i}}$ as the number of correct clas- 
sifications in group $\mathrm{i}$, and $\mathrm{N}$ as the total number of observations, the statistic is calculated as tau $=\left\{\mathrm{N}_{\mathrm{c}}-\Sigma_{\mathrm{i}} \mathrm{p}_{\mathrm{i}} \mathrm{N}_{\mathrm{i}}\right\} /\left\{\mathrm{N}-\Sigma_{\mathrm{i}} \mathrm{p}_{\mathrm{i}} \mathrm{N}_{\mathrm{i}}\right\}$.

\section{REFERENCES}

"A Voter's Guide to the Issues: What They Think." Newsweek (March 16, 1992). Amel, Dean, and J. Nellie Liang. "A Dynamic Model of Entry and Performance in the U.S. Banking Industry." Finance and Economic Discussion Series, Division of Research and Statistics, Division of Monetary Affairs, Federal Reserve Board, Washington, D.C., 1992.

Altman, Edward, Robert Avery, Robert Eisenbeis, and John Sinkey. Application of Classification Techniques in Business, Banking and Finance. Greenwich, Conn.: JAI Press Inc., 1981.

Boeke, J. H. Economics and Economic Policy of Dual Societies. New York, 1953. Bruton, Henry. "The Search for a Development Economics." World Development 13 (October/November 1985).

Cohn, David. Where I Was Born and Raised. Notre Dame, Ind.: University of Notre Dame Press, 1967.

Council of Northeast Economic Action. An Empirical Analysis of Unmet Demand in Domestic Capital Markets in Five U. S. Regions. Boston, Mass.: Research Division, 1981.

Economic Research Service, United States Department of Agriculture. Rural Conditions and Trends: Special Report on Financial Institutions. Supplement 1, Spring 1991.

Espy, Michael, and William Emerson. "A Bill: To Promote Economic Development in the LMDR by Establishing the Lower Mississippi Delta Development Financing Corporation." 102d Congress, 2D Session, H.R. 6188, October 6, 1992.

Feldman, David. "The Trade-off Between GNP and Unemployment in a Dual Economy." Southern Economic Journal 56 (July 1989).

Grabowski, Richard. "Development and Displacement: A Critique and Alternative." The Journal of Developing Areas 23 (July 1989).

Greenwood, Michael. "Research on Internal Migration in the United States: A Survey." Journal of Economic Literature 13 (1975).

Hanushek, E. A. "The Economics of Schooling" Journal of Economic Literature 24, no. 3 (September 1986).

Holtz-Eakin, Donald. "Public Investment in Infrastructure." Journal of Economic Perspectives 7, no. 4 (1993). 
Horvitz, Peter, and Robert Pettit. Small Business Finance: Sources of Financing for Small Business. Greenwich, Conn.: JAI Press, 1984.

Jorgenson, Dale. "The Development of a Dual Economy." Economic Journal 71 (June 1961).

Kendall, Maurice G., and Alan Stuart. The Advanced Theory of Statistics. Vol.3 New York: Hafner Publishing Company, 1968.

Kozal, Jonathon. Savage Inequalities: Children in America's Schools. New York: Crown Publishers Inc., 1991, p.9.

Kuznets, Simon. "Notes on Stage of Economic Growth as a System Determinant."

In Comparison of Economic Systems, edited by Alexander and Eckstein. Berkeley, 1971.

Lawrence, David, and Marie Klugman. "Interstate Banking in Rural Markets: The

Evidence from the Corn Belt." Journal of Banking and Finance 15 (1992).

Lawrence, David, and Thomas Wadkins. "Rural Banking Markets and Holding

Company Entry." Journal of Economics and Business 38 (1986).

Lemann, Nicholas. The Promised Land: The Great Black Migration and How It Changed America. New York: Alfred A. Knopf, 1991.

Lewis, W. Arthur. "Economic Development with Unlimited Supplies of Labour." Manchester School of Economics and Social Studies 22 (May 1954).

Lower Mississippi Delta Development Commission. The Delta Initiatives. Memphis, Tennessee, 1990.

Morris, Charles, and Mark Drabenstott. "Financing Rural Business: What Role for Public Policy." Economic Review, Federal Reserve Bank of Kansas City (September-October 1989).

"Rethinking the Rural Credit Gap." Rural Development Perspectives (October-January 1991).

Myrdal, Gunar. Development and Underdevelopment Cairo: National Bank of Egypt Fiftieth Anniversary Commemoration Lectures, 1956.

. An American Dilemma: The Negro Problem and Modern Democracy. Harper and Brothers, 1944.

Oates, Steven. Let The Trumpet Sound: The Life of Martin Luther King, Jr. Harper, 1982 , p. 345.

Pulver, Glen, and R. Hustedde. "Regional Variables that Influence the Allocation of Venture Capital: The Role of Banks." The Review of Regional Studies 20, no. 3 (1990).

Rainwater, L., and W. Yancey. The Moynihan Report and the Politics of Controversy. Cambridge: MIT Press, 1967.

Ranis, Gustav, and John Fei. "A Theory of Economic Development." American Economic Review 51 (September 1961). 
Rogers, Glenn, Ron Shaffer, and Glen Pulver. "The Adequacy of Capital Markets for Rural Nonfarm Enterprise." The Review of Regional Studies. 20, no. 3 (1990).

Schachter, Gustav, and S. Saul Engelbourg. "The Steadfastness of Economic Dualism in Italy," The Journal of Developing Areas 22 (July 1988).

Smith, Timothy. "Determinants of Rural Growth: Winners and Losers in the 1980's." Research Working Paper, RWP 92-11, Research Division Federal Reserve Bank of Kansas City, December 1992.

Srinivasan, Ali. "Mississippi: A Dual Economy." Economic Review, The Federal Reserve Bank of Atlanta (January/February 1988).

Tweeten, Luther. Foundations of Farm Policy. Omaha: University of Nebraska Press, 1970.

Whalen, Gary. "Actual Competition, Potential Competition, and Bank Profitability in Rural Markets." Economic Review, Federal Reserve Bank of Cleveland, 24 no. 3 (Third Quarter 1988). "The Determinants and Performance Effects of Rivalry In Local Banking Markets." Quarterly Journal of Business and Economics 31, no. 2 (Spring 1992).

Wright, Richard. 12 Million Black Voices: A Folk History of the Negro in the United States. Viking Press, 1941, p. 93. 